\title{
Efek Perlakuan Pembungkusan Terhadap Kualitas Buah Juwet
}

\section{(Effect Bagging Treatment to Quality of Black Plum Fruit)}

\author{
Eko Setiawan ${ }^{1} *$ \\ ${ }^{1}$ Prodi Agroteknologi, Fakultas Pertanian, Universitas Trunojoyo Madura \\ Jl. Raya Telang PO BOX 2, Kamal, Bangkalan, Jawa Timur, Indonesia, Kode Pos 69162 \\ *Email korespondensi: e_setiawan@trunojoyo.ac.id
}

Diterima 21 Desember 2018/Disetujui 14 Januari 2019

\begin{abstract}
The study aimed to determine the quality of juwets (Syzygium cumini) due to packaging. The study was conducted in Kamal District, Bangkalan Regency, in September-November 2016, using 30-year-old juwet trees. The experimental was set up a randomized complete block design (RCBD) with a single factor, bagging and twenty replications with one tree per replicate. The results showed that the sugar content in juwets that were not-bagging ranged from 12.5-14.5 ${ }^{\circ}$ Brix lower than the bagging treatment which ranged from 15.5-16.5 ${ }^{\circ}$ Brix. The anthocyanin content in the week of harvest has decreased. The highest flesh of fruits was produced by the bagging treatment than not-bagging with values of $6.58 \mathrm{~g}$ and $6.30 \mathrm{~g}$, respectively. The highest ratio flesh of fruit and seeds is produced by the fruit bagging with a value around 5.10.
\end{abstract}

Keywords: anthocyanin, ํㅏix, bagging, fruit quality, Syzygium,

\begin{abstract}
ABSTRAK
Penelitian bertujuan untuk mengetahui kualitas buah juwet (Syzygium cumini) akibat pembungkusan. Penelitian dilaksanakan di Kecamatan Kamal, Kabupaten Bangkalan, pada September-November 2016, dengan menggunakan pohon juwet umur 30 tahun. Penelitian disusun menggunakan rancangan acak lengkap dengan faktor tunggal yaitu pemberian sungkup dan diulang sebanyak dua puluh kali. Hasil penelitian menunjukkan kandungan gula pada buah juwet yang tidak dibungkus berkisar antara $12.5-14.5^{\circ}$ Brix lebih rendah dari pada buah yang dibungkus yang berkisar antara $15.5-16.5^{\circ}$ Brix. Kandungan anthocyanin buah pada minggu menjelang panen mengalami penurunan. Kandungan daging buah tertinggi dihasilkan oleh perlakuan diberi sungkup daripada buah tanpa sungkup dengan nilai masing-masing $6.58 \mathrm{~g}$ dan $6.30 \mathrm{~g}$. Rasio daging buah dan biji tertinggi dihasilkan oleh buah disungkup dengan nilai 5.10.
\end{abstract}

Kata kunci: anthocyanin, ${ }^{\circ}$ brix, bungkus, kualitas buah, Syzygium.

\section{PENDAHULUAN}

Juwet, tanaman buah tropis biasa disebut black plum merupakan famili dari Myrtaceae kaya dengan kandungan anthocyanin (Sari et al., 2012; Sri et al., 2013). Saat ini penelitian tentang pewarna alami semakin meningkat seiring dengan kesadaran kesehatan pada pewarnaan sintetik pada makanan, salah satu sumber warna adalah anthocyanin (Jampani et al., 2014). Anthocyanin merupakan group dari water-soluble flavonoids berupa pigment warna yang banyak ditemukan pada buah dan sayuran (Li et al., 2017), seperti pada buah bery, plum dan anggur, responsif pada warna merah menyala, biru dan ungu (Jampani et al., 2014). Warna dan kestabilan kandungan anthocyanin dipengaruhi oleh $\mathrm{pH}$, cahaya, kandungan gula dan lainnya (Sari et al., 2012).

Warna dari buah dikontrol atau dikendalikan oleh konsentrasi dari pigmen anthocyanin, klorofil dan karotenoid (Liu et al., 2013). Warna ungu gelap pada buah juwet menandakan kandungan anthocyanin yang tinggi (Azima et al., 2017). Pigmen anthocyanin pada buah juwet warna ungu gelap mempunyai nilai $\mathrm{R}_{\mathrm{f}} 0.67$ pada spektrum $515 \mathrm{~nm}$, sedangkan warna ungu nilai $\mathrm{R}_{\mathrm{f}}$ berkisar antara 0.52 0.56 pada spektrum 524-525 nm (Sri et al., 2013). Perbedaan warna anthocyanin pada buah juwet dipengaruhi oeh perubahan $\mathrm{pH}$ (Brito et al., 2017). Pada $\mathrm{pH}$ kurang dari 3 dilaporkan wana merah dan ungu lebih dominan, warna biru di atas pH 6 (Sharma et al., 2016). Anthocyanin pada buah juwet berpotensi sebagai pewarna makanan (Sari et al., 2012). Kandungan anthocyanin dari buah juwet dipengaruhi oleh faktor luar salah satunya cahaya (Meng et al., 2015; Sari et al., 2012). Pada buah apel faktor lingkungan yang sangat peting dalam perubahan warna pada kulit adalah cahaya (Meng et al., 2015). Salah satu peningkatan kualitas buah adalah dengan pembungkusan (Bai et al., 2017), karena efektif utuk induksi warna pada buah (Meng et al., 2015). Tujuan dari penelitian ini adalah mengetahui kualitas buah juwet di Madura akibat pembungkusan. 


\section{METODE PENELITIAN}

Penelitian dilaksanakan di Desa Banyu Ajuh, Kecamatan Kamal, Kabupaten Bangkalan. Penelitian dilaksanakan pada bulan September-November 2016, dengan menggunakan pohon juwet (Syzygium cumini (L) Skeels) umur 30 tahun. Data yang diambil meliputi ukuran buah (diameter, panjang), bobot daging buah, bobot biji, pengukuran kandungan gula buah panen ( ${ }^{\circ}$ Brix) menggunakan hand refractometer Atago, Japan; serta pengujian kandungan anthocyanin. Suhu udara di lokasi penelitian diukur dibawah pohon juwet setiap seminggu sekali. Perlakuan terdiri dari pemberian sungkup yang terbuat dari kertas dan tanpa pemberian sungkup. Pemberian sungkup dilakukan pada saat bunga telah mekar. Penelitian disusun menggunakan rancangan acak lengkap yang terdiri dari satu faktor yaitu pemberian sungkup dan diulang sebanyak dua puluh kali. Ekstraksi anthocyanin buah juwet mengikuti metode Sari et al. (2012) yaitu buah juwet dihancurkan dengan blender. Pigmen diekstrak dengan ethanol $98 \%$ (ratio material dan solvent adalah 1:2, w/v) stirring 1 jam, diikuti centrifuse pada 3552 g selama 10 menit. Kemudian didapatkan supernatant dan sisanya diekstrak kembali sebanyak 3 kali. Supernatants di vacuumfilter kemudian di rotavapor pada suhu $40^{\circ} \mathrm{C}$ (Sari et al., 2012). Data yang diperoleh akan dianalisis menggunakan analisis sidik ragam melalui aplikasi SPSS 17, hasil uji yang berbeda nyata selanjutnya akan diuji lanjut dengan uji BJND (Beda Jarak Nyata Duncan) dengan taraf 5\%.

\section{HASIL DAN PEMBAHASAN}

Hasil penelitian menunjukkan bahwa bobot buah perlakuan sungkup lebih tinggi dari pada tanpa sungkup, hal ini diduga dipengaruhi oleh ukuran diameter buah yang lebih besar pada perlakuan sungkup. Dengan bobot biji yang tidak berbeda nyata maka daging buah yang lebih tebal dihasilkan oleh perlakuan sungkup (Tabel 1). Panjang buah berkisar antara 3.57-3.58 cm sedangkan diameter buah berkisar antara 1.83-186 cm. Rasio panjang/diameter buah lebih tinggi pada perlakuan tidak disungkup yaitu 1.96 dan pada perlakuan disungkup rasio sekitar 1.92. Persentase daging buah juwet yang tidak disungkup dan disungkup sekitar $83.11 \%$ dan $83.61 \%$. Alokasi karbohidrat untuk buah pada perlakuan sungkup menghasilkan rasio daging buah/biji tertinggi yaitu 5.10 sedangkan pada buah juwet tanpa sungkup menghasilkan rasio daging buah/biji sebesar 4.92. Daun berhubungan erat dengan laju fotosintesis dan hasilnya akan disimpan oleh tanaman dalam bentuk berat kering (Setiawan, 2009).

Pada Gambar 1 menunjukkan bahwa buah juwet yang disungkup warna daging buahnya lebih terang ada semburat warna merah, sedangkan yang tidak disungkup lebih gelap. Pembungkusan sangat efektif untuk meningkatkan kualitas buah terutama yang berhubungan dengan perkembangan warna pada buah pir merah telah merubah preferensi konsumen karena kelihatan lebih menarik serta nilai gizinya (Bai et al., 2017). Warna merah pada daging buah peach meningkat seiring dengan pemberian bungkus pada buah (Liu et al., 2015). Untuk meningkatkan warna pada buah beberapa praktek manajemen di perkebunan buah telah diterapkan dintaranya pengurangan daun serta perlakuan pembungkusan buah (Bai et al., 2017).

Pada Gambar 2, kandungan gula pada buah juwet yang tidak dibungkus lebih rendah dari pada buah yang dibungkus, secara berurutan masing-masing dengan nilai antara 12.5-14.5 ${ }^{\circ}$ Brix serta $15.5-16.5{ }^{\circ}$ Brix. Chaudhary et al. (2014) melaporkan juwet mempunyai kandungan TSS sebesar $12.3{ }^{\circ}$ Brix, sehingga hasil penelitian ini menunjukkan bahwa kandungan gula total pada buah juwet yang dibungkus sangat tinggi. Hasil penelitian juga bertentangan dengan Feng et al. (2014) pembungkusan buah menyebabkan konsentrasi padatan terlarut (SSC) buah apel 'BC-2 Fuji' lebih rendah dibandingkan dengan yang tidak dikantongi. Konsentrasi sukrosa dalam kulit dan daging meningkat secara bertahap dalam pembungkusan (Feng et al., 2014). Penelitian sebelumnya pada buah manggis dilaporkan bahwa kualitas buah yang baik rata-rata dihasilkan oleh ranting bagian dalam yang tidak terkena cahaya matahari secara langsung (Setiawan and Poerwanto, 2008), dan pembungkusan buah dapat meningkatkan kualitas terutama penampilan visual buah (Setiawan et al., 2012).

Hasil penelitian menunjukkan pada buah juwet tanpa disungkup kandungan anthocyanin lebih tinggi dibandingkan buah juwet yang disungkup, masing-masing secara berurutan dengan kisaran 124.6-143.3 mg.100g ${ }^{-1}$ dan 119.5-136.0 mg.100g ${ }^{-1}$ (Gambar 2). Baik pada perlakuan diberi sungkup maupun tidak disungkup nilai kandugan anthocyanin pada buah juwet masih lebih rendah dari yang dilaporkan Suradkar et al. (2017) mencapai $185.35 \mathrm{mg} .100 \mathrm{~g}$ 1. Feng et al. (2014) melaporkan warna merah pada kulit buah apel lebih rendah pada kondisi dibungkus; pembungkusan meningkatkan tingkat kecerahan permukaannya, dan menghambat pewarnaan serta akumulasi anthocyanin. Pada buah yang dibungkus kandungan pati lebih tinggi dan degradasi pati tertunda sebagian, hal tersebut menjelaskan SSC rendah. Faktor eksogen yang mempengaruhi akumulasi anthocyanin pada kulit apel merah, termasuk kondisi cahaya dan suhu (Honda et al., 2016). Hasil penelitian menunjukkan kandungan anthocyanin pada buah juwet meningkat setelah minggu ke-4. Selanjutnya kandungan anthocyanin relatif konstan antara minggu ke 5-7. Hal tersebut diduga dipengaruhi oleh kondisi suhu yang meningkat pada minggu 5 menyebabkan tekanan akumulasi anthocyanin pada buah juwet (Gambar 3). Suhu yang lebih hangat selama seminggu sebelum panen menekan sintesis anthocyanin dan menurunkan ekspresi faktor transkripsi MYB dan gen-gen sintetis anthocyanin di kulit apel 'Gala' (Honda et al., 2016). 
Tabel 1. Perbandingan atribut fisik buah juwet perlakuan tanpa sungkup dan pemberian sungkup.

\begin{tabular}{lccccccccc} 
Pelakuan & $\begin{array}{c}\text { Bobot } \\
\text { buah }(\mathrm{g})\end{array}$ & $\begin{array}{c}\text { Panjang buah } \\
(\mathrm{cm})\end{array}$ & $\begin{array}{c}\text { Diameter } \\
\text { buah }(\mathrm{cm})\end{array}$ & $\begin{array}{c}\text { Rasio } \\
\text { Panjang: } \\
\text { Diameter }\end{array}$ & $\begin{array}{c}\text { Bobot } \\
\text { daging }(\mathrm{g})\end{array}$ & $\begin{array}{c}\text { Persen } \\
\text { daging } \\
\text { buah }(\%)\end{array}$ & $\begin{array}{c}\text { Berat } \\
\text { biji }(\mathrm{g})\end{array}$ & $\begin{array}{c}\text { Persen } \\
\text { biji } \\
(\%)\end{array}$ & $\begin{array}{c}\text { Rasio daging } \\
\text { buah:biji }\end{array}$ \\
\hline $\begin{array}{l}\text { Tanpa } \\
\text { Sungkup }\end{array}$ & 7.58 & 3.58 & 1.83 & 1.96 & 6.30 & 83.11 & 1.28 & 16.89 & 4.92 \\
Sungkup & 7.87 & 3.57 & 1.86 & 1.92 & 6.58 & 83.61 & 1.29 & 16.39 & 5.10 \\
\hline
\end{tabular}

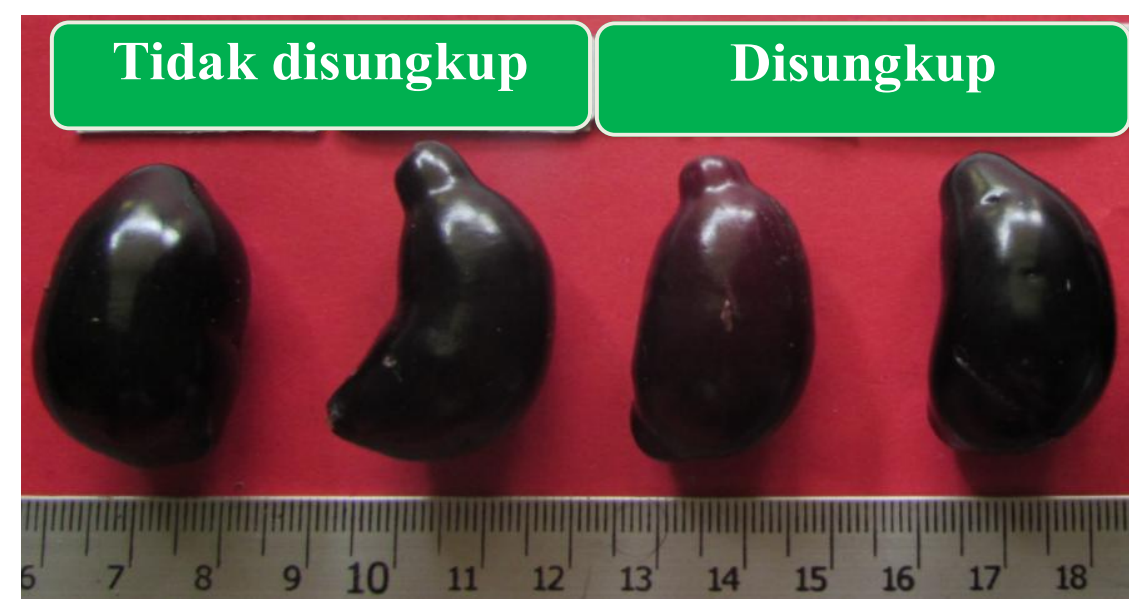

Gambar 1. Penampilan buah juwet yang dipanen umur 7 minggu, dari kiri nomer 1 dan 2 perlakuan buah tidak diberi sungkup; dari kiri nomer 3 dan 4 perlakuan buah diberi sungkup.

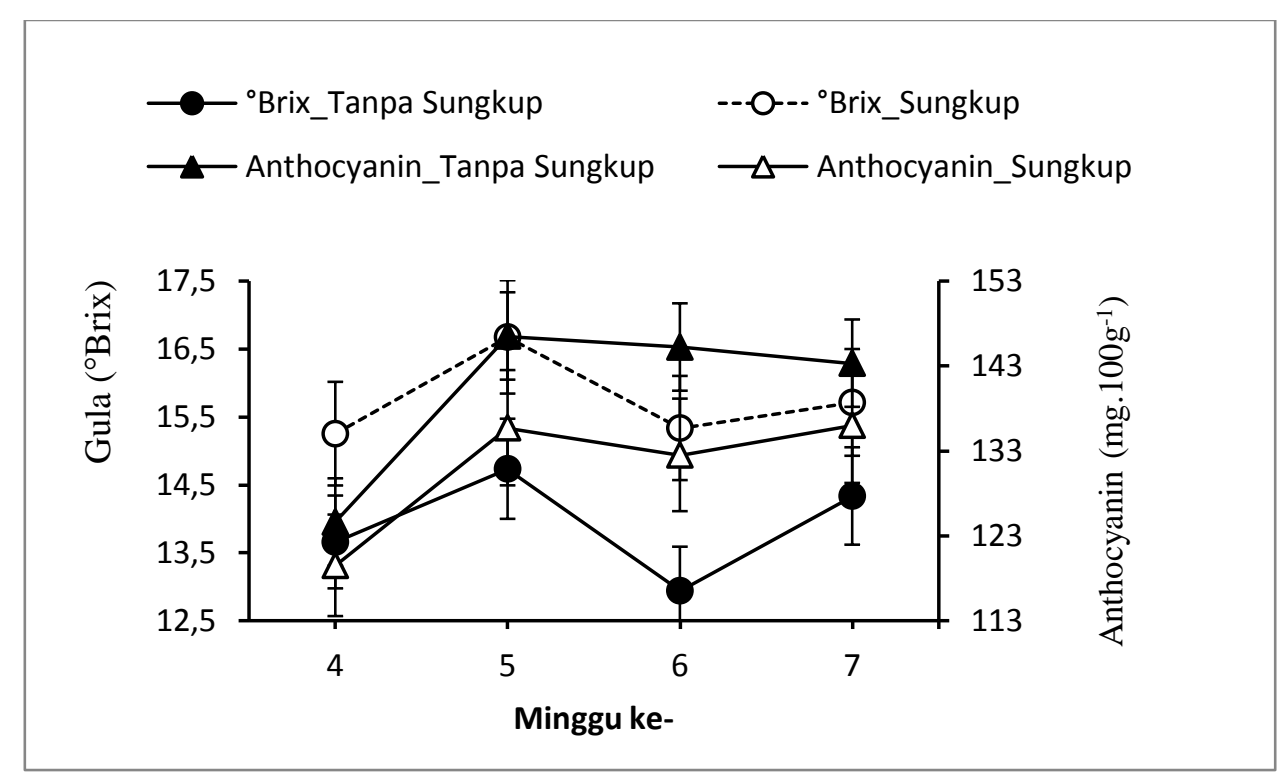

Gambar 2. Perubahan kandungan gula ( ${ }^{\circ}$ Brix) dan anthocyanin pada buah juwet dengan perlakuan diberi dan tidak diberi sungkup. 


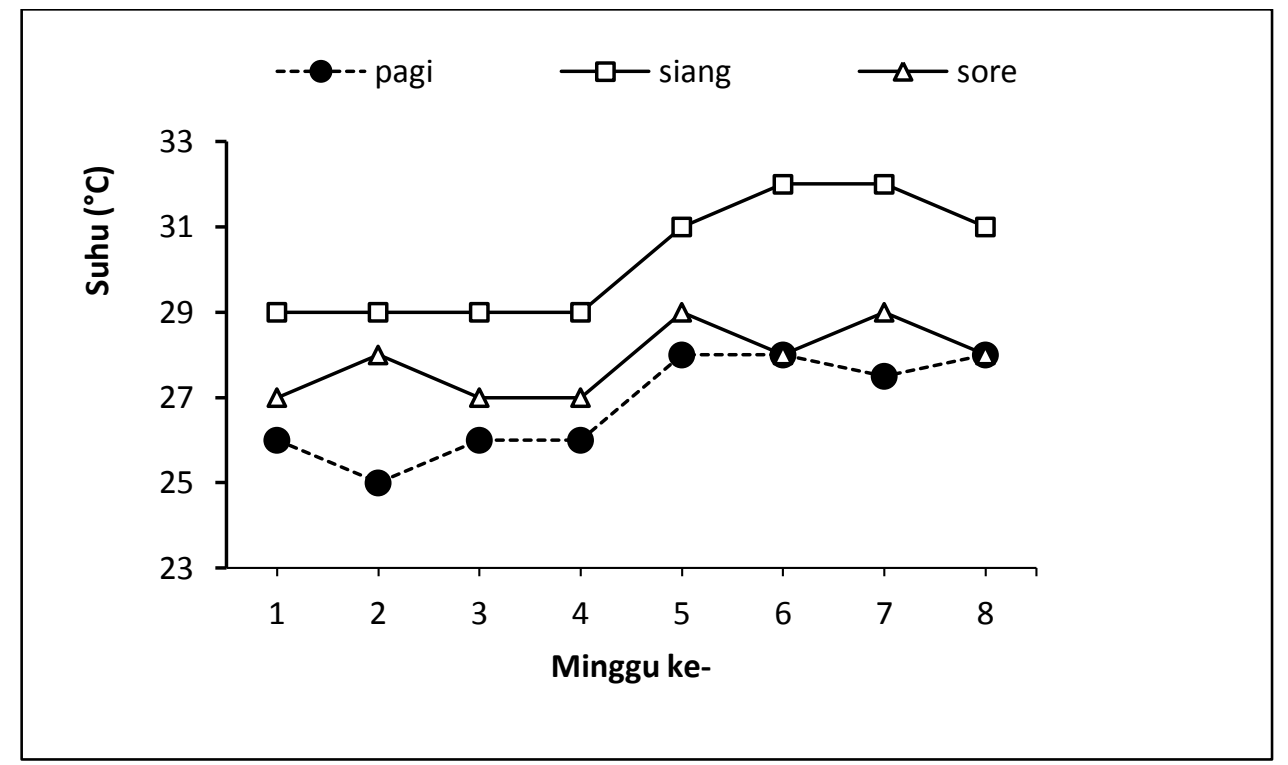

Gambar 3. Suhu harian yang diukur pada pagi, siang dan sore hari selama penelitian.

\section{KESIMPULAN}

Hasil penelitian menunjukkan kandungan gula pada buah juwet yang tidak dibungkus lebih rendah dari pada buah yang dibungkus, secara berurutan masing-masing dengan nilai antara 12.5-14.5 ${ }^{\circ}$ Brix dan 15.5-16.5 ${ }^{\circ}$ Brix. Buah juwet yang diberi sungkup memberikan warna daging buah gelap agak kemerahan. Kandungan anthocyanin buah pada minggu menjelang panen mengalami penurunan atau stagnan diduga karena pengaruh suhu yang meningkat mulai minggu ke-5 sampai minggu ke-7 menjelang panen. Kandungan daging buah tertinggi dihasilkan oleh perlakuan diberi sungkup daripada buah tanpa sungkup dengan nilai masing-masing $6.58 \mathrm{~g}$ dan $6.30 \mathrm{~g}$. Rasio daging buah dan biji tertinggi dihasilkan oleh buah disungkup dengan nilai 5.10 .

\section{DAFTAR PUSTAKA}

Azima, A.M.S., A. Noriham, N. Manshoor. 2017. Phenolics, antioxidants and color properties of aqueous pigmented plant extracts: Ardisia colorata var. elliptica, Clitoria ternatea, Garcinia mangostana and Syzygium cumini. J. Funct. Foods 38:232-241.

Bai, S., Y. Sun, M. Qian, Y. Fengxia, J. Ni. 2017. Transcriptome analysis of bagging- treated red Chinese sand pear peels reveals light-responsive pathway functions in anthocyanin accumulation. Sci. Reports 7(63):1-15.

Brito, B. de N. do C., R. da S. Pena, A.S. Lopes, R.C. Chiste. 2017. Anthocyanins of jambolao (Syzygium cumini): extraction and $\mathrm{pH}$-dependent color changes. J. Food Sci. 1-5.

Chaudhary, C., B.S. Yadav, R.B. Grewal. 2014. Preperation of red wine by blending of grape (Vitis vinifera L.) and jamun (Syzygium cuminii L. Skeels) juices before fermentation. Int. J. Agric. Food Sci. Technol. 5(4): 239-348.

Feng, F., M. Li, F. Ma, L. Cheng. 2014. The effects of bagging and debagging on external fruit quality, metabolites, and the expression of anthocyanin biosynthetic genes in 'Jonagold' apple (Malus domestica Borkh.). Sci. Hortic. (Amsterdam). 165: 123-131.

Honda, C., H. Iwanami, K. Naramoto, T. Maejima, K. Kanamaru, Y. Moriya-tanaka, M. Wada. 2016. Thinning and bagging treatments and the growing region influence anthocyanin accumulation in redfleshed apple fruit. Japanese Soc. Hortic. Sci. 9:1-9.

Jampani, C., A. Naik, K.S.M.S. Raghavarao. 2014. Purification of anthocyanins from jamun (Syzygium cumini L.) employing adsorption. Sep. Purif. Technol. 125:170-178.

Li, D., P. Wang, Y. Luo, M. Zhao, F. Chen. 2017. Health benefits of anthocyanins and molecular mechanisms: update from recent decade. Crit. Rev. Food Sci. Nutr. 57(8): 1729-1741.

Liu, T., S. Song, Y. Yuan, D. Wu, M. Chen, Q. Sun, K. Chen. 2015. Improved peach peel color development by fruit bagging. Enhanced expression of anthocyanin biosynthetic and regulatory genes using white non-woven polypropylene as replacement for yellow paper. Sci. Hortic. (Amsterdam). 184:142148.

Liu, Y., X. Zhang, Z. Zhao. 2013. Effects of fruit bagging on 
anthocyanins, sugars, organic acids, and color properties of 'Granny Smith' and 'Golden Delicious' during fruit maturation. Eur. Food Res. Technol. 236: 329-339.

Meng, R., D. Qu, Y. Liu, Z. Gao, H. Yang, X. Shi, Z. Zhao. 2015. Anthocyanin accumulation and related gene family expression in the skin of dark-grown red and non-red apples (Malus domestica Borkh.) in response to sunlight. Sci. Hortic. (Amsterdam). 189:66-73.

Sari, P., C. Hanny, D. Sajuthi, U. Supratman. 2012. Colour properties, stability, and free radical scavenging activity of jambolan (Syzygium cumini) fruit anthocyanins in a beverage model system: natural and copigmented anthocyanins. Food Chem. 132(4):1908-1914.

Setiawan, E. 2009. Pengaruh empat macam pupuk organik terhadap pertumbuhan sawi (Brassica juncea L.). Embryo 6(1):27-34.

Setiawan, E., R. Poerwanto. 2008. Produktivitas dan kualitas buah manggis (Garcinia mangostana L.) di
Purwakarta. Agrovigor 1(1):10-18.

Setiawan, E., R. Poerwanto, F. Fukuda, N. Kubota. 2012. Meteorological conditions of mangosteen orchard in West Java, Indonesia and seasonal changes in C-N ratio of their leaves as affected by sector (position in canopy) and tree age. Sci. Reports Fac. Agric. Okayama Univ. 101(1):39-47.

Sharma, R.J., R.C. Gupta, S. Singh, A.K. Bansal, I.P. Singh. 2016. Stability of anthocyanins- and anthocyanidinsenriched extracts, and formulations of fruit pulp of Eugenia jambolana ('jamun'). Food Chem. 190:808817.

Sri, S., L. Priya, P.R. Devi, P. Eganathan, J. Kingsley. 2013. In vitro antimicrobial activity of Syzygium cumini fruit peel and identification of anthocyanins. Afr. J. Pharm. Pharmacol. 7(25):1719-1728.

Suradkar, N.G., V.S. Pawar, D.M. Shere. 2017. Physicochemical, proximate and bioactive composition of jamun (Syzygium cuminii L.) fruit. Int. J. Chem. Stud. 5(3):470-472. 